\title{
システムニューロサイエンス教育講座
}

\author{
17. 前 頭 眼 野 \\ 一視覚入力・眼球運動出力に関する体制化一
}

鈴木 寿夫

\section{Topographical Organization of the Frontal Eye Field in Terms of Sensory and Motor Aspects}

\author{
Hisao Suzuki \\ Department of Physiology, School of Medicine, Tokyo Medical and Dental University
}

The frontal eye field (FEF) is topographically organized in terms of sensory input from the environmental space as well as oculomotor output. Many visual neurons are located in the FEF. Those located in the lateral part of the FEF have the visual receptive field in the foveal region of the contralateral visual field, while those in the medial part have the visual receptive field in the eccentric region from the fovea. Many oculomotor neurons are also found in the FEF, the activation of which elicits saccadic eye movements of a particular amplitude and direction, depending on their location in the FEF: activation in the lateral part of the FEF induces a saccade with a small amplitude, while activation in the medial part induces a large saccade. The destination of the saccades is always in the contralateral visual hemifield. The visual and oculomotor neurons located at a given part of the FEF area related. A saccade elicited by activation of the oculomotor neurons is generally directed to the most responsive area in the receptive field of the visual neurons, suggesting that a transfer of neuronal activities from the sensory neurons to the motor neurons induces visually-guided eye movements. In addition, the FEF exhibits an inhibitory effect on oculomotor initiation and holds the image of the visual object to the foveal region. Activation of FEF neurons representing the foveal region suppresses saccade generation. Furthermore, this suppressive effect of the lateral part of the FEF functions even when a visual object is moving. Electrical activation of this area elicits slow eye movement resembling a smooth pursuit eye movement. Spike activities are also seen in neurons in this area during smooth pursuit eye movements. Based on these facilitatory and inhibitiory functions, the FEF may contribute to the generation of normal orientation behavior, which is composed of selecting a particular object in the environmental space, visual fixation on the object for an appropriate duration, and shifting from the object to other objects in proper time.

Keywords: frontal eye field, topographical organization, saccadic eye movement, visual fixation, smooth pursuit eye movement 

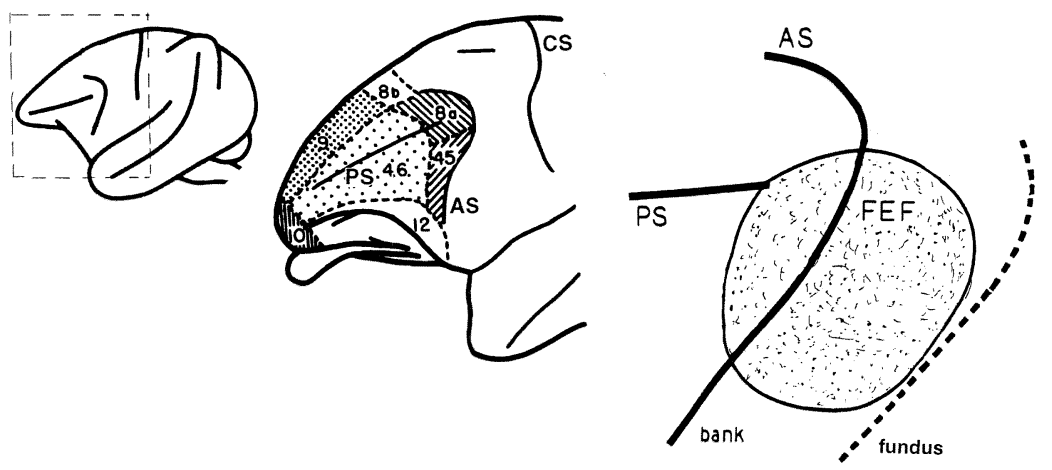

図 1 サル前頭眼野 (FEF) の局在

大脳皮質前頭葉（左図の点線で囲まれた部分）のWalker による細胞構築的区分（文献 1 から改変)。CS: 中心溝, PS: 主溝, AS: 弓状溝。8a 野と45野が前頭眼野 (FEF) である。FEF は右図に示したように, 皮質表面の露出部に続き，弓状溝の前壁を深部に向かって底（点線）まで拡がっている。この図は，溝の 譬を拡げたように描いている。

\section{目次}

1.はじめに

2. 前頭眼野の知覚・運動の二面的性質

3. 前頭眼野の知覚入力に関する局所地図的体制

4. 前頭眼野の運動出力に関する体制化

5. 知覚入力体制と運動出力体制の関連

6. 前頭眼野と上丘体制の関係

7. サッケード発動の制御 (抑制) 領野

8. smooth pursuit に関する役割

9. まとめと問題点

\section{1. はじめに}

前世紀から，ヒトの前頭前野 (prefrontal cortex）の尾側が臨床的に执かされると眼球運動の 異常が生じることが知られていた。この事から， この皮質領域は, 眼球運動と密接に関係があるだ ろらと考兄られた。その後, サル前頭前野の特定 範囲を実験的に電気刺激すると，共同眼球運動 (conjugate eye movement) が生じることがわか った。そして, この眼球運動が生じる範囲こそが 動眼領域であろらといらことから，「前頭眼野」 (frontal eye field; FEF) と呼ばれるよらになっ た。しかし，初期に和いては強い電気刺激がもち いられた結果，刺激効果が遠くまで拈よび，皮質 の広い範囲の刺激で眼球運動が生じたので, 前頭 前野の広領域が「前頭眼野」であると考兄られた。 その後, だんだんに脳の限局部位を刺激する事が 可能になり，この方法によって動眼領域がマッピ ングされ，「前頭眼野」は次第に限局されていっ
た。近年，皮質内微小刺激法 (intracortical microstimulation; 微小電極を使って皮質内のきわめて 限局した微小部分を刺激する方法)によって，「前 頭眼野」は，サルの前頭前野の背外側部にある弓 状溝前壁 (the anterior bank of the arcuate sulcus）とその露出皮質の縁（the lip of the sulcus） に特定された。それは, Walker の細胞構築学的 分類では 8 a 野と 45 野に相当する (図 1 参照) 1 。 この領野は組織的に同種皮質（isocortex）で，乙 かもその内 6 層構造を持つ同型皮質 (homotopic cortex）に属する。5 層, 6 層には比較的大きな錘 体細胞が見られる。

同型皮質である皮質領域は，一般に連合野（association cortex) と呼ばれる。連合野は高次な複 雑な機能を示す所で, それを生理学的に解析する のは容易ではない。その一つの原因は，そこに局 所地図的な体制（topographical organization）を 見出し難いことによる。前頭眼野では, 幸いにし て近年視覚空間ならびに眼球運動に関しての特有 な局所地図的体制が見出され，それに沿った分析 がなされつつある。以下，この体制を中心述べ たい。文献はこの話題に直接関係のあるもののみ を選んだ。

\section{2. 前頭眼野の知覚・運動の二面的性質}

サルの前頭眼野を一側破壊すると, 反対側半視 野に現れた刺激を無視するよらになる2)。この時 無視した半視野に一致して弱視 (amblyopia) が 生じ, 刺激の検出閾値が上昇している3)。このよ 
A

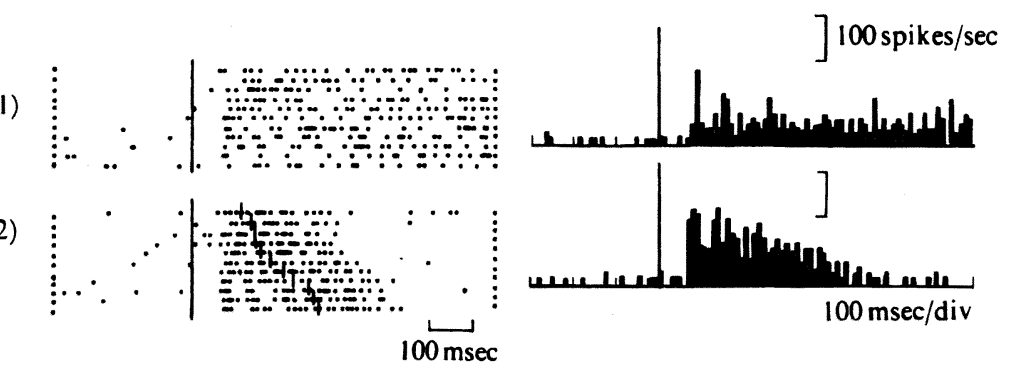

B

(1)

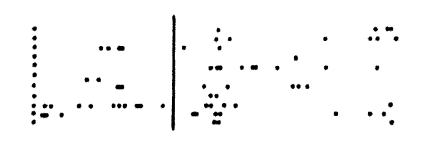

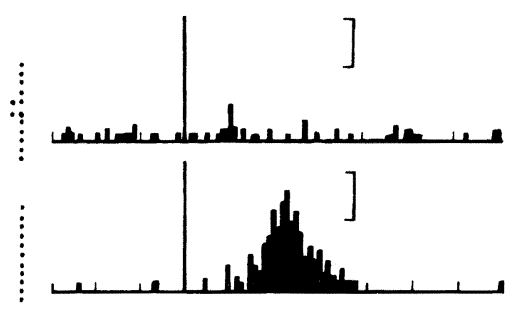

図 2 前頭眼野でみられるニューロン活動

$\mathrm{A}:$ 視覚性ニューロン。(1)：受容野内に視覚刺激を呈示したときのニューロン反応。左側の縦棒から終 わりまで視覚刺激が呈示された。各点がニューロン・スパイクを示し，1列が 1 回の試行の結果を示す。 何れの試行でも, 光刺激の呈示によって持続的発火が生じている。右側にこの反応を単位時間毎に加算平 均したヒストグラムを示した。(2)：受容野内に呈示した視覚刺激に向かってサッケードが生じた時の二 ューロン反応。長い縦棒の所で刺激が呈示され，短い縦棒の所でサッケードが生じた。初期のニューロン 反応が (1) 飞比較して増大している。

B : サッケードニューロン。(1): 光刺激を呈示（綐棒の所）しただけではニニーロン反応はほとんぞ 生じない。(2)：その光刺激に向かってサッケードが生じる（左のドット・ディスプレイでの各々の短縦 棒がサッケード開始時点）と，数十ミリ秒先行して活動を開始する。

ら飞前頭眼野の破壊は「物を見る」といら知覚の 障害を引き起こすが，同時に「眼球を対象物に向 ける」(注視 ; foveation) といら運動の障害も引 き起こす。前頭眼野の一側を破壊すると, 眼球位 置の偏向を来たし, 視線を一定の方向に向けられ なくなる4)。両側を破壊すると, 眼球運動の減少 が生じる。これらの症状は数週間で軽減する。し かし, 前頭眼野の両側破壊と上丘の両側破壊と組 み合わせると,サッケードは汪とんど出来なくな り，それが永続する5)。

以上から, 前頭眼野は, 視覚刺激の検出とそれ に対する注視といら機能面での知覚と運動の二面 性をもっているよらに思われる。このことは, 電 気生理学的な研究からもわかる。無麻酔無拘束下 のサル FEF のニューロン活動は微小電極を使っ て調べられた6)。FEFには, 次の種類のニューロ ンが存在する。(1)視覚性ニューロン（visual neurons）(図 $2 \mathrm{~A})^{7) 8)}$ 。これは, 視野の特定部分に視
覚刺激を呈示すると, 数十ミリ秒の潜時をもって 発火する(図 $2 \mathrm{~A}-1$ )。この視覚刺激に向かって サッケードが生じるとニューロンの反応増強 (enhancement) がみられる(図 $2 \mathrm{~A}-2)^{8)}$ 。(2)サ ッケードニューロン(saccade neurons) (図 2 B ) 8)。 これは, 視覚ニューロンと違って視野の特定部分 に視覚刺激を呈示するだけでは発火しない（図 2 B-1)8)。視覚刺激に向かってサッケードすると， その開始時間に数十ミリ秒先行して, しかもその 時間にロックして発火する（図 2 B-2）。しかし， 自発サッケード（spontaneous saccade）時には 活動しない。(3)視覚・運動性ニューロン（visuomovement neurons)。(1)と(2)の両方の性質を兼 ね備えているものである。このよらな多様な二 ニーロンの存在は, 前頭眼野に和ける視覚入力か ら眼球運動出力への変換過程を示していると想像 できる。 
Equilibrium Res Vol. 57(5)

A
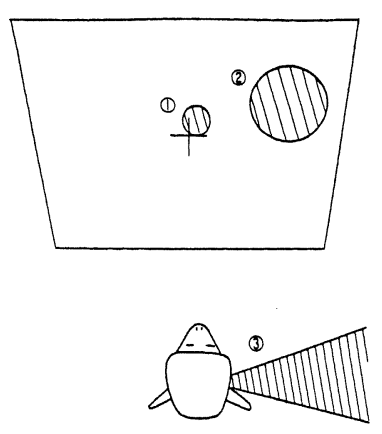

B

(1)
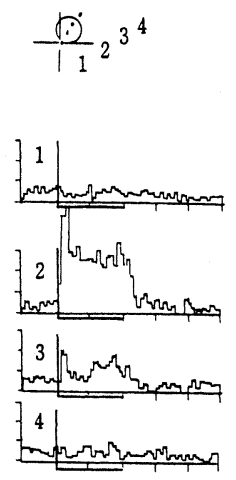
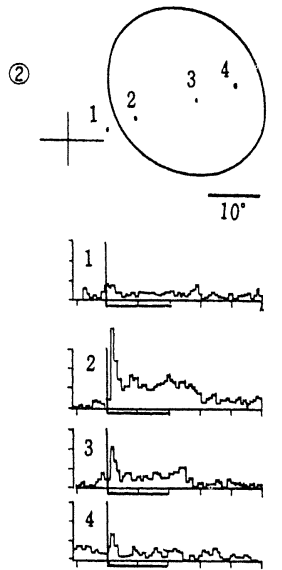

C

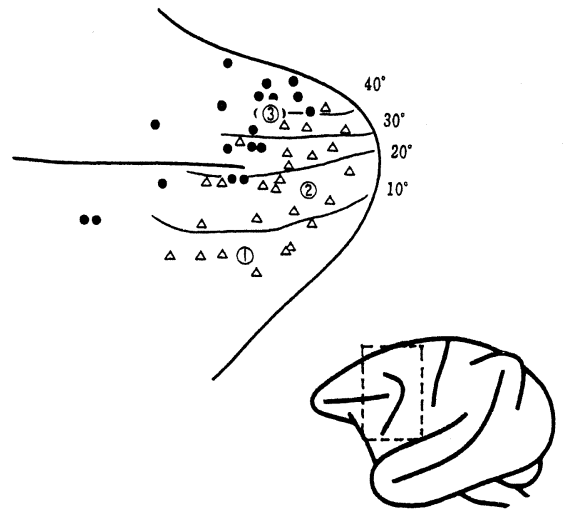

(3)

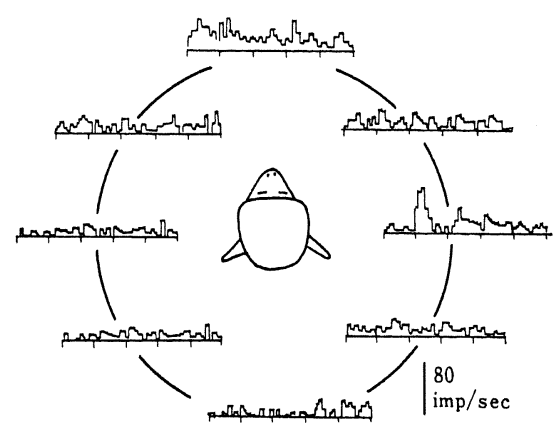

図 3 前頭眼野の視覚性扐よび聴覚性ニューロンの受容野と皮質上の分布

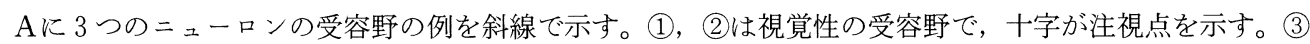
は聴覚性の受容野。これらのニューロンの活動が光スポット刺激（1)，(2)，聴覚刺激（3)の位置とと もにどのように変化するかを，Bにヒストグラムで示した。Cは視覚性ニューロン(三角)と聴覚性ニュー ロン（黒丸）の前頭眼野に乱ける分布。10-40の網膜偏心度の受容野を持ったニューロンの平均的な位 置を等高線で示した。前頭前野外側にあるニューロンの受容野は網膜中心部にあり, 内側に移るにつれ て, ニューロンの受容野は網膜中心部から周辺部に移る。

\section{3. 前頭眼野の知覚入力に関する局所地図的体 制}

さて，上述の視覚性ニューロンは，FEF 内に 不規則に存在するのではない。視覚空間について 局所地図的体制（topographical organization）が 存在する7)。前頭眼野の外側部に存在するニュー ロンは動物周囲空間の中心部分（真直前の部分） を再現（represent）している。前頭眼野の内側 部になると、ニューロンは周辺部を再現するよう になる。図 $3 \mathrm{~A}$ にとのことを模式的に示した。 (1)と(2)の斜線の領域は，2つのニューロンが，視 覚刺激に対してそれぞれ反応する視野内の範囲 (受容野)を示す。それらのニューロンが記録さ
れた前頭眼野皮質上の位置をCに示した。ニュー ロンの受容野の空間内での位置と, 皮質上での位 置は密接に関連していた。皮質の外側から内側に 向かって, ニューロンの受容野の中心窩からの距 離（網膜偏心度 ; eccentricity）が大きくなった。 しかし, 各ニューロン受容野の中心窩からの方向 には，一定の規則性はなかった。隣接するニュー ロンの受容野の偏心度はだいたい一致している が，方向は一致しないことがしばしば見られた。

皮質上での空間の再現は, 視覚といら一つの感 覚種 (modality) にとどまっていない。視野の外 側で視覚入力が利用できない部分にある音源に応 答する聴覚性ニューロン（A，B の（3）が見出さ 


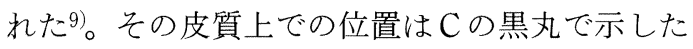
ように, 最も周辺に受容野をもつ視覚性ニューロ ンの記録される部位か，さらに内側であった。す なわち前頭眼野は視覚入力だけでなく, 聴覚入力 も含めて動物の周囲空間全体を再現している。視 覚入力が利用できない部分は聴覚入力でそれを補 っていると考光られる10)。

前頭眼野は, 周囲空間の中心から周辺まで余す ところなく再現している。このよらな体制の基礎 は, より低次の脳構造から前頭前野への入力経路 に求めなければならない。そこで上述の体制の解 剖学的背景を明らかにするために, 前頭眼野にお ける中心再現領域と周辺再現領域を電気生理学的 に同定したあと，それぞれの領域に HRP を注入 し, 逆行性に標識された起源細胞の分布を観察し た11)。図4 はそれを模式的に示したものである。 前頭眼野での視野中心部之周辺部の再現領域に投 射する細胞には, その場所的分布にはっきりした 差が見出された。前頭眼野は, 側頭葉後部, 後頭 葉の吻側部，下頭頂葉にかけた広い範囲から投射 を受ける。前頭眼野の外側部 (視野中心再現領域) は，下側頭回及び前月状皮質外側部から投射をら ける。一方, 前頭眼野内側部 (周辺再現領域) は 上側頭回, 下頭頂小葉, 及び前月状皮質内側部か ら投射をらける。下側頭回には中心窩に関連した 機能があり, 前月状皮質外側部は視野中心を再現 することが知られている。一方, 前月状皮質内側 部は視野周辺部を再現して和り，また上側頭回， 下頭頂小葉は運動視のような中心窩以外の機能を 持つことが知られている。したがって, 前頭眼野 の外側部及び内側部之, それらに投射する皮質領 域には機能的一致がみられ，前頭眼野にみられる 中心一周辺という体制は，そこに投射する皮質諸 領域の機能分化によって生じることが強く示唆さ れる。

\section{4 . 前頭眼野の運動出力に関する体制化}

一方, 眼球運動出力の体制化はどらであろら か。この問題に立ち入る前に, 前頭眼野に多数存 在するサッケード・ニューロン一つ一つが, 特定 のベクトルのサッケード発生にどのよらに関わっ ているかが問題となる。サッケード・ニューロン には, 運動域 (movement field) がある8)。サル が視野中心に現れた視標 (第一視標) を注視して いるとき，この第一視標を消す。同時に，離れた
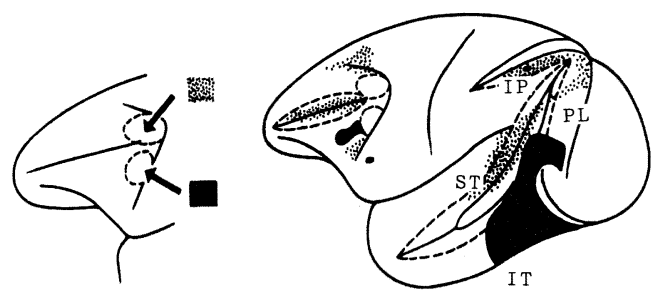

図 4 前頭眼野への投射の起始部位

下側頭回後部, 前月状回外側部“黑で塗り つぶした部分）から中心視野再現領域（前 頭眼野外側部） へ, 上側頭回, 前月状回内 側部, 下頭頂小葉（小点の部分）から周辺 視野再現領域（前頭眼野内側部）一投射す る。IT: 下側頭回, PL: 前月状回, ST: 上側頭回, IP: 頭頂小葉。

所（図 5 の DIRECTION SERIES では視角 20) に第二の視標を呈示する。すると，第二視標に向 からサッケードが生じ（これを視覚誘導性サッ ケードといら), サッケードに先行したニューロ ン反応がみられる。この反応は, 第二視標の提示 方向を系統的に変光, 生じるサッケード・ベクト ルの方向を変えると変化する。ここでは，3つの 万向での反応のみ示している。反応は注視点から $15^{\circ}$ の方向（視野中央から水平子午線に沿って右 方向を $0^{\circ}$ とし, 左回りの角度）ではきわめて弱 く, $60^{\circ}$ で最大となり，その後また弱くなり， 1050できわめて僅かとなる。AMPLITUDE SERIES では，第二視標の提示方向を DIRECTION SERIES で最大反応が得られた $60^{\circ}$ に固定し, 第一視標から第二視標までの距離を変えることに よって, 生じるサッケード振幅を系統的に変化し た。ニューロン反応は，50でほとんど見られず， $15^{\circ}$ で明瞭となり, $45^{\circ}$ でさらに増大する。この よらに, サッケードの振幅, 方向を系統的に変 え, ニューロン反応が, 視野のどの範囲内の点に 向かってサッケードした時生じるかを決める。こ の範囲をサッケード・ニューロンの運動域 (movement field; 右図の点線で囲まれた範囲) といら。ニューロンは, 運動域内のあらゆる点に 向かって生じるサッケード誘発に参画している。 このように決められたサッケード・ニューロンの 運動域は, 一般に広く, 境界ははっきりしないこ とが多い。

$$
\text { 以上から,一つのサッケード・ニューロンは, }
$$




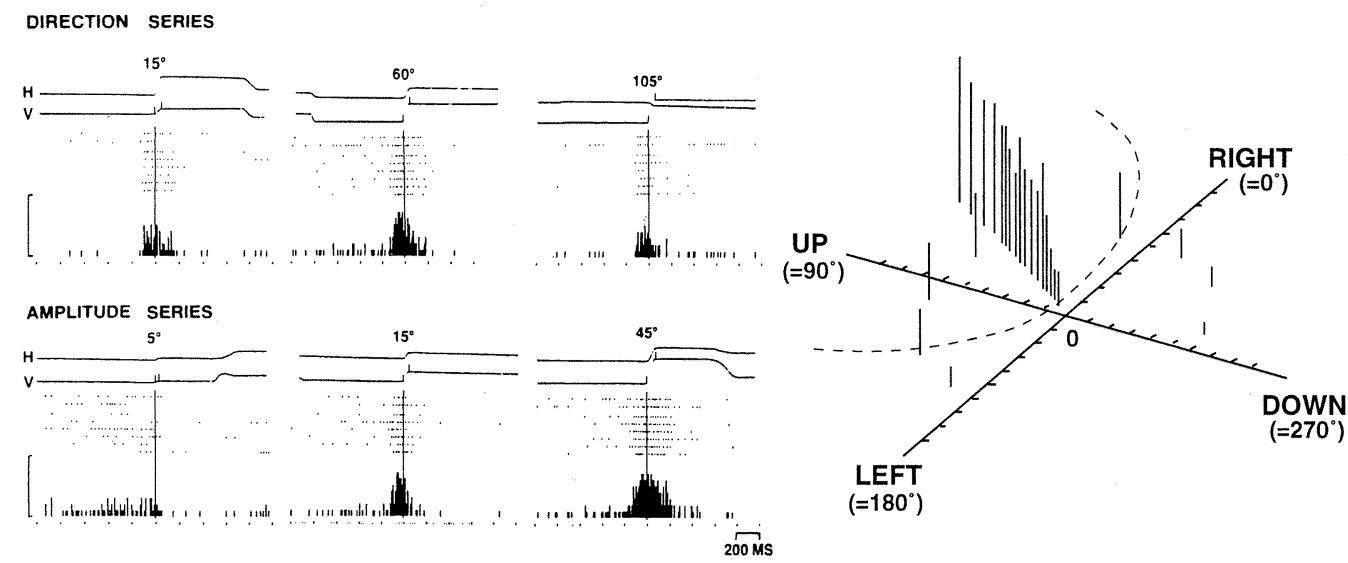

図 5 前頭眼野サッケード・ニューロンの運動域 (movement field)

左図 : DIRECTION SERIES では, サルが視野中心を注視しているとき, そこから視角 $20^{\circ}$ 離れた所に 第二の視標を呈示し，それに向から視覚誘発サッケードを生じさせる。このとき第二視標の視野中心から の提示方向を系統的に変える。各々の場合のニューロン活動を, ドット・ディスプレイと反応ヒストグラ ムで示す。ここでは, 視野中央から水平子午線に沿って右方向を $0^{\circ}$ とし, 左回りの角度でサッヶード・ ベクトルの方向を示す。代表的な 3 つの方向に向から視覚誘発サッケード時のニューロン反応が示されて いる。AMPLITUDE SERIES では, 第二視標の呈示方向をニューロン反応がよく出る $60^{\circ}$ に固定し, 呈示する距離を系統的に変克, 生じるサッケード振幅を変化させたときのニューロン反応を示す。ここで も, 代表的な 3 つの振幅の二ューロン反応が示されている。

右図 : DIRECTION SERIES と AMPLITUDE SERIES で得られたニューロン反応の大きさ（Z軸）を， サッケード・ベクトル面 $(\mathrm{X}, \mathrm{Y}$ 軸) 上にプロットした。得られるサッケード・ベクトル面の範团がニュー ロンの反応野となる（点線で囲をれた範囲）(文献 8 を改変)。

広範囲の方向・大きさのサッケード誘発に関わっ ていることがわかる。換言すれば，特定のただ一 つのニューロンの活動が特定の方向と特定の大き さの視覚誘導性サッケードを起こすのではない。 ある特定のニューロン集団の活動（activation） が生じることによって，はじめて特定の方向・大 きさのサッケードが成立すると思われる。つま り，ある特定のサッケード・ニューロンの集団活 動が，小さな振幅のサッケードを引き起こし，別 のニューロンの集団活動が大きなサッケードを起 こすといらょうに，それぞれのニューロン集団が 機能分担しているのである。そこで，前頭眼野に 特けるサッケード・ベクトルの体制を調べるに は, 特定サッケード・ベクトルを誘発するニュー ロン集団の体制を調べなければならない。

特定のニューロン集団を活動させる方法に皮質 内微小電気刺激 (intracortical microstimulation) がある。微小電極を皮質内に刺入し，その先端か ら電流を流し近在するニューロン集団を人工的に 刺激する方法である。しかし，この方法を適用で きるのは, 近在するニューロンが類似の機能を担
っている場合である。すなわち, 近在するニュー ロン集団が特定サッケード・ベクトルの誘発に寄 与していなければならない。幸い, 前頭眼野に特 いてはこのような条件を満たしているようにみえ る。

図 6 A に示した例では, 先端部分を約 $20 \mu \mathrm{m}$ 露出した微小電極を右側前頭眼野皮質に刺入し, 記録の下の短い横線のところで, 電気刺激（1 リ秒幅の矩形波, 5 ミリ秒間隔, 10発）し, 誘発 サッケードを, 光学式オクロメータで記録した。 2 つの記録トレースは, 水平眼位（上方の振れが 右方への眼位変動, 逆は左方), 垂直眼位 (上方 の振れが上方, 逆は下方) を表わす。50 $\mu \mathrm{A}$ の陰 性電流で刺激すると, 右上方向から振幅約 $20^{\circ}$ のサッケードが誘発された。この強さの刺激電流 が電極先端に流れれば, 電極先端に近在する相当 数のニューロンが興奮すると思われ，したがって 生じたサッケードはニューロン集団活動の結果と いえる。これらのニューロン集団が特定のサッ ケード・ベクトル発生に関与するだろらか。また は，それぞれのニューロンが異なるサッケード・ 

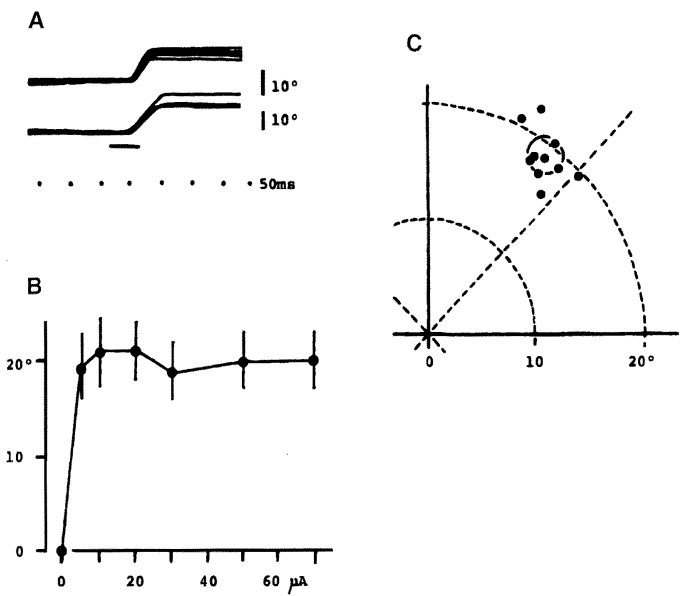

図 $6 \mathrm{~A}$ : 微小電気刺激によって誘発されたサッ ケード。2つの記録トレースは, 光学式オ クロメータで記録された水平眼位（上方の 振れが右方), 垂直眼位（上方の振れが上 方）を表わす。記録の下の短い横線のとこ ろで, 強さ $50 \mu \mathrm{A}$ の陰性電気刺激（1 ミ リ秒幅の矩形波, 5 ミリ秒間隔, 10発) を 左側前頭眼野に与えた。 B : 刺激の強さを 徐々に増した時の誘発サッケードの振幅。 閾上刺激によって誘発したサッヶードの振 幅は，試行ごとにばらつきを示すほかは， ほぼ一定であった。それぞれの縦棒が誘発 されたサッケード振幅の半数を含む範囲を 示す。 $\mathrm{C}: 50 \mu \mathrm{A}$ で10回刺激したときの誘 発サッケード・ベクトルの各終点とそれら の半分を含む円。

ベクトル発生に関与し，ベクトル和として一つの サッケード・ベクトルが誘発されるのだろらか。 このいずれであるかは, 電極先端に流れる刺激電 流の強さを変え, 刺激されるニューロンを変えて みればわかる。弱い電流は, 電極のごく近傍の二 ューロンだけを刺激するが，刺激を強くすれば刺 激されるニューロンの範囲は拡がる。もし, 電極 周囲のニューロン集団が，特定サッケード・ベク トルの誘発に寄与しているならば, 刺激強度を変 化し刺激されるニューロンの数を増してもサッ ケード・ベクトルは変化しないであろら。反対 に，それぞれのニューロンがそれぞれ異なるサッ ケード・ベクトル発生に関与し，その単純なベク トル和として一つのサッケード・ベクトルが誘発 されるならば, 刺激強度を変化し興奮するニュー ロン数を増せば, サッケード・ベクトルは刺激強 度と共に連続して变化するであろら。図 $6 \mathrm{~B}$ に
その結果を示す。刺激電流の強さを上げていく と, 刺激は閾值に達しサッケードが生じるように なる。しかし, さらに刺激電流を増加させても， サッケード・ベクトルの終点は試行ごとにばらつ くが（図 6C の円は全終止点の半分を含む），汪 汪一定である。このような微小刺激の条件下で は, 近傍のサッケード・ニューロン集団は特定の サッケード・ベクトル誘発に寄与していると結論 づけられる。

以上の結果から, 微小刺激を前頭眼野の各部に あた光, 各部位のニューロン集団を興奮させれ ば，それぞれが担当しているサッケード・ベクト ルがわかる。図 $7 \mathrm{~A}$ では, 微小電極を下の模式 図に示した刺入点より前頭眼野内側部に刺入し, 進入路に沿って異なる深さで刺激した。誘発サッ ケード・ベクトルは, 刺激点の深さと共に変化し た。前頭眼野の背内側では, 露出部ないし弓状溝 前壁浅部刺激で, 誘発サッケードの振幅は一般に 大きい。しかし，深部になるにしたがい，振幅は 小さくなる。

さらに, 微小電気刺激誘発サッケード・ベクト ルは, 弓状溝に関する内外側軸に関して变化する (図 7 B $)^{12)}$ 。刺激電極の刺入点が前頭眼野内側で は, $25^{\circ}$ のよらな大振幅サッケードが誘発される が，外側になると $1.4^{\circ}$ のよらな小さなサッケー ドが誘発されるようになる。

以上から, 前頭眼野の運動出力体制は, 次の上 らに考觉られる。前頭眼野内側のサッケード・ニ ューロン集団は, 大さなサッケードを誘発し，外 側になるとそれらは小さなサッケードを誘発す る。また, 弓状溝浅部の二ューロンは比較的大き なサッケードを誘発し，深部になるにつれて小さ なサッケードを誘発するようになる。

\section{5. 知覚入力体制と運動出力体制の関連}

以上から，前頭眼野に拈いては，動物周囲空間 に関して外側部はその中心部分を分担し, 内側部 は周辺部を分担する。また, 運動出力に関して外 側部は小さなサッケード誘発を担当し, 内側は, 大きなサッケード誘発を担当する。これら，知覚 入力と運動出力の局所地図的体制がぞのように関 連しているであろらか。それを知るために，ま ず,一つの微小電極を使って, 視覚ニューロンを とらえ視覚受容野の範囲を決める。次に, 同じ電 極から微小電気刺激を行いサッケードを誘発させ 
A

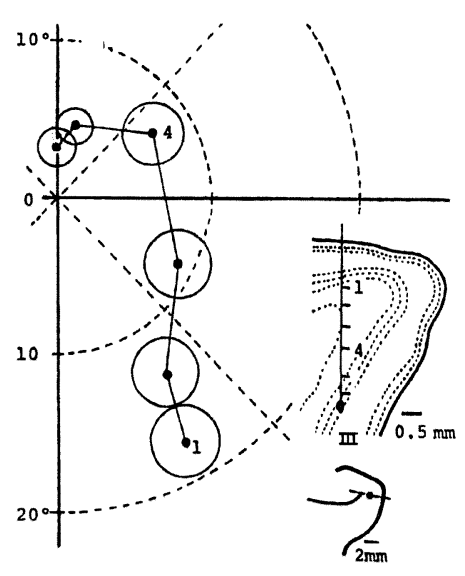

B

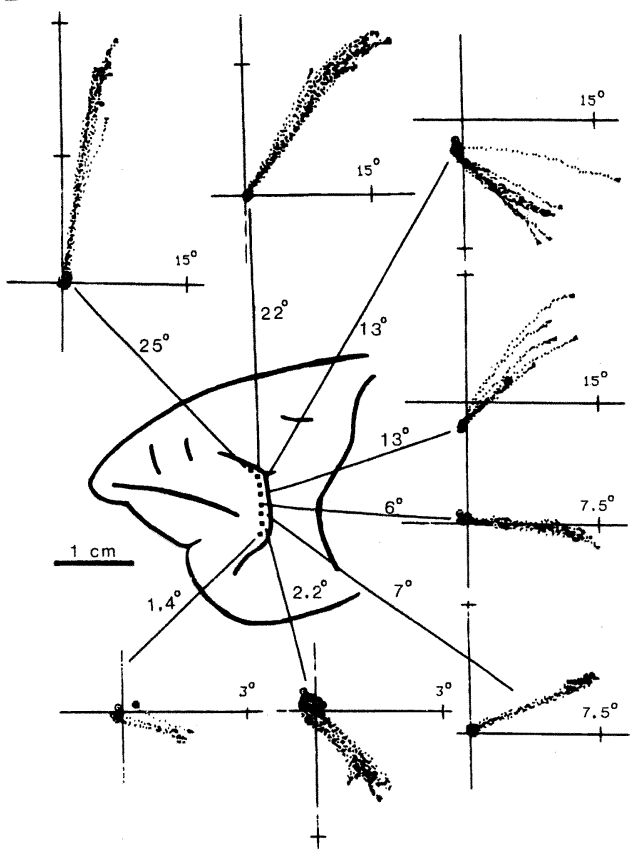

図 $7 \mathrm{~A}$ : 微小電気刺激誘発サッケードの弓状溝の浅深軸に関しての变化。微小電極を下の模式図に示した刺入 点より FEF 内側部に挿入し, 模式的に示した進入路の各深さで刺激した。各深さごとに, 誘発サッケ一 ド・ベクトルの終止点を半数含む円と, メデアン終止点を示した。この例では, 露出部ないし弓状溝前壁 浅部刺激では，誘発サッケードの振幅は大きい。しかし，深部になると振幅は小さくなる。

$\mathrm{B}$ : 微小電気刺激誘発サックード・ベクトルの弓状溝内外側軸に関しての変化。刺激電極の刺入点が前頭 眼野内側では, $25^{\circ}$ の大振幅サッケードが誘発されるが, 外側となると $1.4^{\circ}$ の小さなサッケードが誘発 される(B図は文献12から改変)。

る。その結果，次のような関係があることがわか った13)。サッケード・ニューロン群によって生じ る急速眼球運動（サッケード）は，近傍にある視 覚性ニューロンの受容野に向かって生じる。前頭 眼野の外側部で捉えたニューロンは，上述したよ らに網膜中心窝部に近い比較的狭い受容野をもっ ている（図 8-1）。このニューロンがとれた部位 を微小電気刺激すると受容野内の最大視覚反応を 得た部分に向からサッケードが生じる。受容野と サッケード・ベクトルの関係は, 電極刺入部が内 側になりニューロンの受容野が網膜中心窩から離 れ大きくなっても変わらない。図8-2にみられ るよらに, サッヶードは, その受容野の内最大視 覚反応を得た部分に向から。さらに内側になる と, ニューロンの受容野は中心窩から離机受容野 の周辺部を大きく占めるよらになる。このような ときでも, 受容野の最大視覚反応部とそこに向か

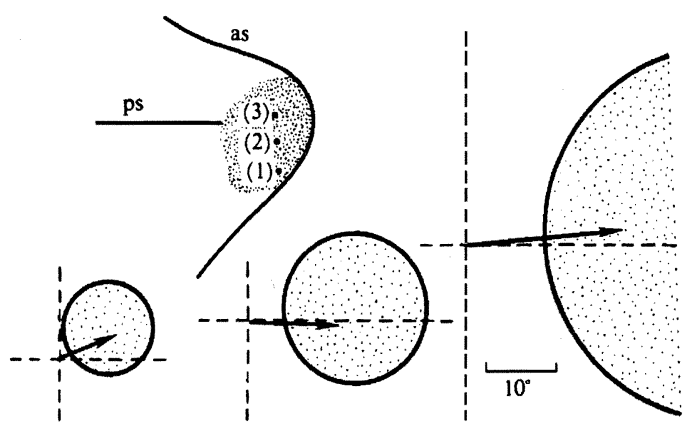

(1)

(2)

(3)

図 8 微小電気刺激誘発サッケードとその近傍二 ューロンの視覚受容野の関係 前頭眼野の外 (1), 中 (2), 内側（3）で の微小電気刺激で誘発されたサッケード と, それぞれの近傍の視覚性ニューロンの 受容野。内側に行くにしたがってニューロ ンの受容野が網膜中心窩から離れ，大きく なる。ps: 主溝, as: 弓状溝。 


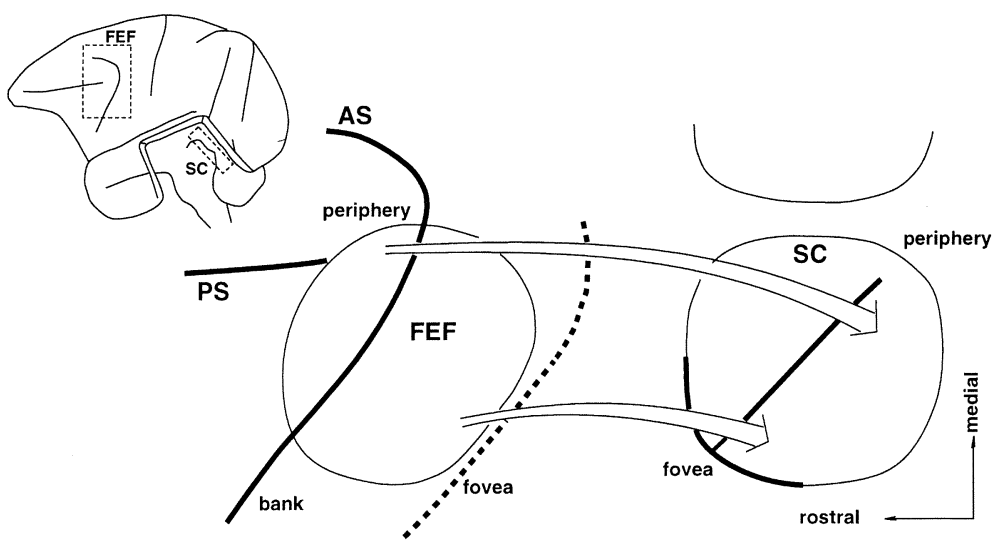

図 9 前頭眼野に拈汁る視覚入力一眼球運動出力系の網膜地図的体制化

前頭眼野の腹外側部は中心視野（fovea）を再現し，背内側部にいくと再現は周辺視野（periphery）飞移 る。サッケードは，丁度その視野の再現部分に向かって生じるように体制されている。前頭眼野の最大の 投射標的である上丘に向から投射線維にも，同じ体制化がある。前頭前野の中心視野再現領域からは，上 丘の中心視野再現領域である吻側部へ，周辺視野再現領域からは，上丘の周辺視野再現領域である尾側部 へ投射する。

らサッケード・ベクトルの関係は保たれる（図 8 $-3)$ 。

\section{6. 前頭眼野と上乒体制の関係}

以上から，前頭眼野では，視覚性入力ニューロ ンがあり，外側から内側にかけて，視野の中心か ら周辺へと再現するように体制化されている。そ れぞれの入力ニューロンの近傍には, 入力ニュー ロンが再現する視野の部分に向かってサッケード を誘発する運動出力ニューロン群がある。そこ で, 視覚入力が対応する視覚ニューロンの活動を 引き起こし，それが近傍の運動ニューロン群に伝 えられる。すると, その部分が受け持っている空 間に向かって眼球運動が生じる。つまり，視覚性 入力ニューロン情報の視野中心一周辺の外側一内 側といら体制化が，運動出力にも反映している。 このよらな視野中心一周辺の体制は，前頭眼野の 最大の投射部位である上丘でもみられる。前頭眼 野の視野中心再現領域と周辺再現領域をそれぞれ 同定したのち，それぞれの領野に HRP を注入 し，上丘内に標識された神経終末の分布を調べた 14)15)。図 9 に模型的に示したように, 前頭眼野の 外側部（すなわち視野中心再現領域）は上丘の前 外側部に, 内側部（すなわち周辺再現領域）は上 丘の後内側部に投射していた。上丘の前外側部は 視野中心を，上丘後部の内側部は周辺部を再現し
ていることが知られている16)。したがって前頭眼 野から上丘への投射は, 前頭眼野に拉ける視野再 現の体制を保ってなされていることが分かる。

\section{7.サッケード発動の制御（抑制）領野}

前頭眼野は，周囲空間及び眼球運動発動機能に ついて外側から内側に向かって体制化されている ことがわかった。その体制化は，運動発動のみな らず，その制御ないし抑制にまで拉よんでいる。 臨床的にもそれに対応する症状が知られている。 前頭眼野の一部が破壊されると, 目立つ視覚対象 物に対する反射的サッケードを抑觉ることが出来 ないことがある17)。これと反対に，特定の対象物 を注視し続け，他の対象物が現れても容易にそれ に向からサッケードが生じない障害もまれにみら れる。この症状は “attention stare”とか “spasm of fixation”とよばれる18)。これらサッケード発 動を制御ないし抑制する機構は，視野中心担当領 域によって行われていると思われる。次の二つの 実験事実がある。

第一は, 前頭眼野の外側に, 注視ニューロン (visual fixation neuron) が存在することである 19)20)。このニューロンは，サルが静止している視 標を見つめている間, 持続的に発火を続ける（図 10A)。さらに，視標を消しても注視行動が続い ている時，発射が持続する (図10B)。このニュー 
A

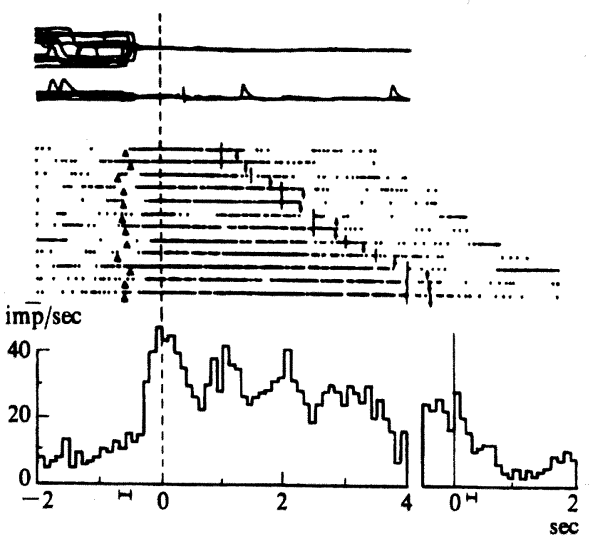

B

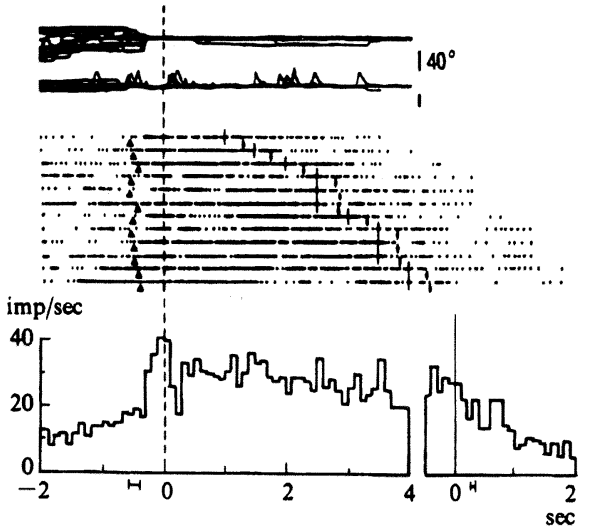

図10 注視ニューロン

A：「注視視標ありスケジュール」下での ニューロン活動。内は注視光を呈示した時 点, 破線はテコ押しを示す。注視光は実線 の所でわずかに明るくなり, サルは, テコ をはなしジュースを得る。ニューロンは注 視視標があるとき，注視間中，持続的に発 火する。

B：「注視視標なしスケジュール」下での ニューロン活動。内で注視光を呈示。破線 の所でテコを押すと注視光は一旦消兄, 実 線の所で再び点燈する。これをテコはなし でジュースを得る手掛かりとする。サルは 再点登する所を注視し続け, ニューロンは 持続的に発火を続ける。

ロンは決して光刺激に受動的に反応して発火して いるのでなく, サッケードを積極的に抑光, 注視 を支觉ていると考光られる。

第二は, 注視ニューロンが多数存在する前頭前 野の視野中心を担当している外側部分では, 微小 電気刺激はサッケードを誘発するのでなく, 逆に 視覚誘発サッケード出現を抑制する（図11参照）
21)22)。いま，サルが注視しているスクリーン中央 の第一の光スポットを消し, 同時に第二の光スポ

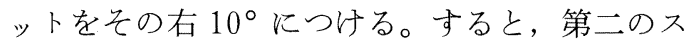
ポットに向からサッケードが潜時200-225ミリ秒 で生じる（水平眼位記録 no st）。第二の光スポッ 卜呈示々同時に, 微小電気刺激（1 ミリ秒幅の矩 形波, 5 ミリ秒間隔）を視野周辺再現領域（背内 側部）に500ミリ秒（S と表示した横線）間与え た（図11A）。このとき，11，16，24 $\mu \mathrm{A}$ と刺激強 度を次第に增しても，この第二光スポットによっ て誘発された視覚誘導性サッケードの潜時は, 䚾 とんど変わらない。さらに刺激強度を増し，背内 側部に対する微小電気刺激の強さが $37 \mu \mathrm{A}$ にな ると, サッケード誘発の閾值に達し, 左下方に向 から振幅 $34^{\circ}$ の電気誘発サッケードが発生した。 眼位はしばらくの間そこに留まり, 電気刺激終了 後に第二の光スポットに向から視覚誘導性サッ ケードが生じた。この部位は, 微小電気刺激によ って左下方に向から振幅 $34^{\circ}$ の大きなサッケー ドが生じる。したがって，第二の光スポットに対 して生じる視覚誘導性サッケードの潜時の大幅の 遅れは, 電気誘発サッケードの干渉の結果生じた と考えられる。

図11B でも, 図 A と同様, 第二光スポットへ 視覚誘導性サッケードさせている。しかし, 今度 は視覚誘導性サッケードを誘発させる第二光スポ ット呈示と同時に, 前頭眼野の中心視野再現領域 である腹外側部に微小電気刺激を与兄, この強度 を 7 から $70 \mu \mathrm{A}$ まで, 徐々に増していった。す ると, 視覚誘導性サッケードの潜時は, 電気刺激 なしのときの 225 ミリ秒から次第に遅れ, $70 \mu \mathrm{A}$ ではその遅れは600ミリ秒にも達した。しかも， この中心視野再現領域は, $70 \mu \mathrm{A}$ にも達する強い 微小電気刺激（1 ミリ秒幅の矩形波, 5 ミリ秒間 隔）を500ミリ秒間も与えても，サッケードは誘 発されなかった。したがって，この刺激強度を徐 徐に増した時の潜時の連続的な遅れは, 電気刺激 によってサックードが誘発された結果ではない。 この部位にサッケード誘発を抑觉る機構が存在す ることを示している。

\section{8. smooth pursuit に関する役割}

以上から，前頭眼野にはサッケードの発動ばか りではなく，それを積極的に抑宎，視覚対象物の 像を中心窩に留める機構が存在することがわかっ 
A
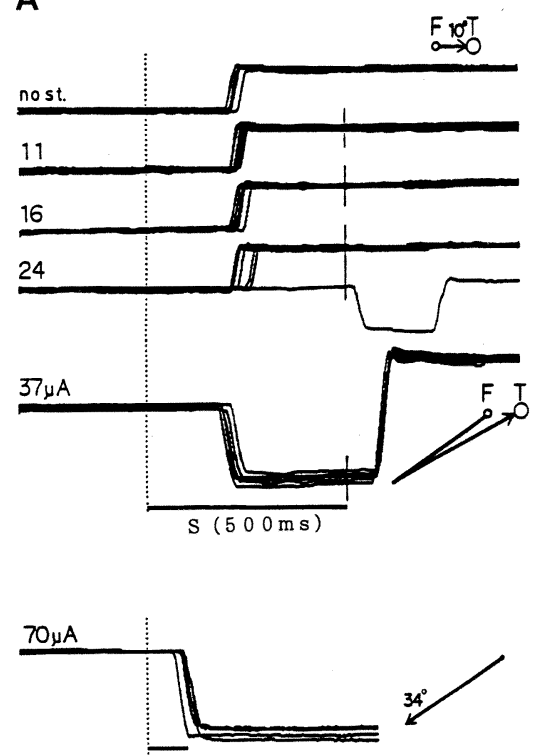

B
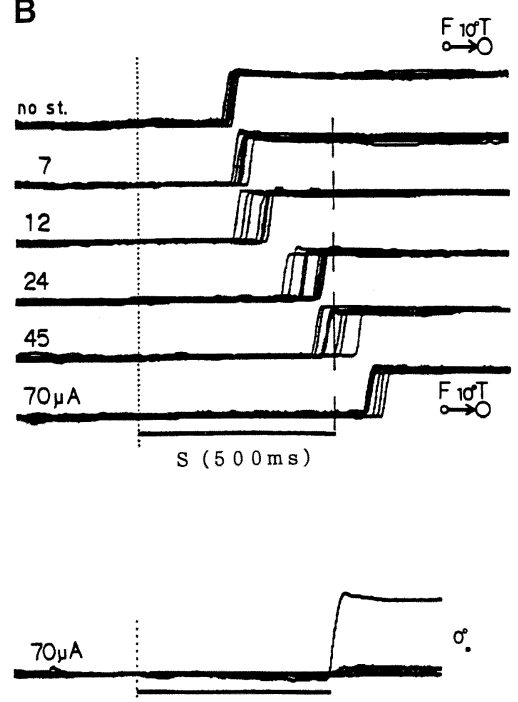

図11＼cjkstart前頭眼野微小電気刺激の視覚誘導性サッケードへの効果

スクリーン中央の第一光スポットを消し（縦破線の所），同時にこのスポットの右 $10^{\circ}$ に第二の光スポッ トをつける。すると，それに向かって潜時200-225ミリ秒でサッケードが生じる。(A， B の no st)。A： 第二スポット呈示と同時に, 前頭眼野の周辺視野再現領域（背内側部）飞微小電気刺激（1ミリ秒幅の矩 形波, 5 ミリ秒間隔) を500ミリ秒間与えた。 $11,16,24 \mu \mathrm{A}$ と刺激強度を増しても, 視覚誘導性サッケー ドの潜時は，ほとんど变化しない。刺激強度が $37 \mu \mathrm{A}$ となると閾值に達し，左下方に向から振幅 $34^{\circ}$ の 電気刺激サッケードが発生し眼位はそこに留まり, 刺激終了後に視標に向からサッケードが生じる。最下 の記録では, 微小電気刺激のみ与皇た。左下方に向から振幅 $34^{\circ}$ の大きなサッケードが生じた。B：A 之同様に第二光スポット呈示々同時に，中心視野再現領域（腹外側部）飞微小電気刺激を与兄，その刺激 強度を 7 から $70 \mu \mathrm{A}$ まで増した。視覚誘導性サッケードの潜時が著明に遅れる。下の記録は, この領域 では強く長い微小電気刺激（1ミリ秒幅の矩形波, 5 ミリ秒間隔, $70 \mu \mathrm{A}, 500$ ミリ秒間）を与兄ても, サ ッケードが誘発されないことを示した。

た。この機構は視覚対象物が静止している時に限 らず，それが動いている時にも機能しているよう にみえる。視覚対象物が視覚空間を動けば, 滑動 性眼球運動（smooth pursuit）が起こり, その像 を中心窩に保持しょらとすることはよく知られて いるが, 近年, 前頭眼野の内弓状溝深部に滑動性 眼球運動を調節する領域があることが明らかにな った。弓状溝深部を破壊すると滑動性眼球運動の 利得が落ち, 動く視標に追従しがたくなる23)。と くに, 視標の動きを予測して追従する能力が著し く低下するといら24)。さらに，この領域に比較的 弱い繰り返し微小電気刺激を与えると, 遅いス ムースな連続した眼球運動が誘発される（図12 A) ${ }^{25)}$ 。この遅い眼球運動は, 電気誘発サッケ一 ドと異なり，刺激皮質と同側方向に向から。この ことは, 一側前頭眼野障害時に原則として障害皮
質と同側方向の遅い眼球運動が障害を受ける事と よく一致する。また，弓状溝前壁の浅側のみを破 壊したのでは, 遅い眼球運動に影響を与えないと いら。弓状溝基底部を破壞するとはじめて, 遅い 眼球運動に障害があらわれるといら。

上述の部位 (弓状溝基底部)では, 多くのニュー ロンが遅い眼球運動時に応答する事が見出されて いる26)。しかも, この種のニューロンは急速眼球 運動時には応答しないといら。これらのニューロ ン発火に対する最適な追従眼球運動の方向は, 原 則としてこの部分で電気刺激によって誘発された 遅い眼球の方向と一致するといら。さらに, 電気 刺激による遅い眼球運動は, 注視期間中でもたや すく引き起こすことができること，これらニュー ロンの発火が遅い眼球運動に先行して開始される こと等の事実から，前頭眼野はサッケードのみな 
Equilibrium Res Vol. 57(5)
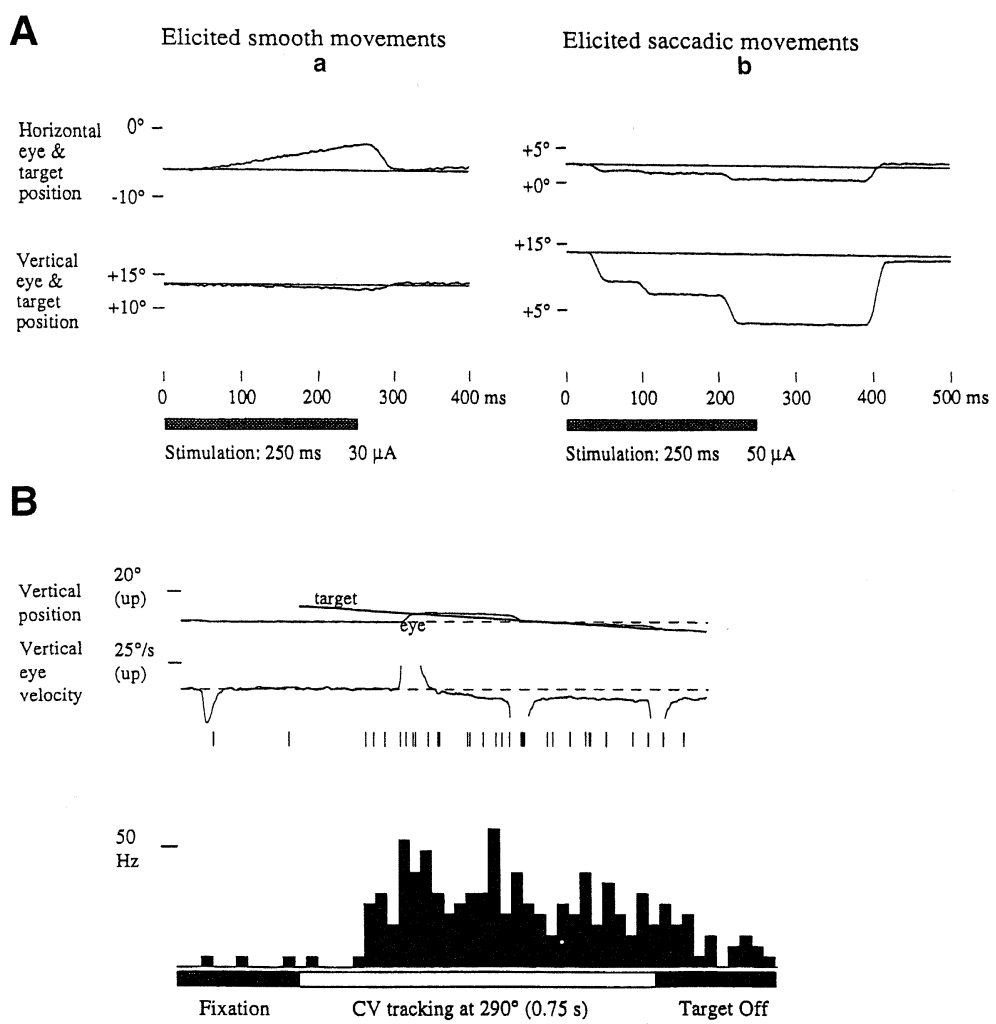

図12 A：前頭眼野微小電気刺激で誘発した遅い眼球運動。サルが中心視野にある視標を注視しているときに， 微小繰り返し刺激（0.2 ミリ秒幅の矩形波，3 ミリ秒間隔，250ミリ秒間）を与兄た。そのとき，刺激によ って眼球が動き眼位が変われば，それと同じよらと視標を自動的に動かし，常に視標が眼の中心位置にく るように（網膜誤差が $0^{\circ}$ となるよらに）している。aでは，電気刺激によって水平方向に遅い持続した 眼球運動が生じている。 bでは, $\mathrm{a}$ と異なる所を $\mathrm{a}$ と同じ条件で刺激した。微小繰り返し刺激によって, 階段状に 3 回サッケードが起きるだけである（文献25から改変）。

B : 滑動性眼球運動時に活性化する前頭眼野ニューロン。視標（target）を視野上方から下方へ一定速度 で動かすと, 視標を眼で追ら滑動性眼球運動が生じる。そのときのニューロン活動を反応ヒストグラムで 示した。2 番目の記録は眼の移動速度を示す。このようなニューロンは, 微小電気刺激によって遅い眼球 運動が誘発される領域（弓状溝基底部）に見られる。また，視標注視時やサッケード時には活性化しない (文献26から改変)。

らず，遅い眼球運動の開始と維持にも関与してい ると考えられる。

\section{9. まとめと問題点}

前頭眼野は, 動物の周囲空間を広く再現して未o り，周囲空間のどこに対象物 (刺激) が現れても， 視覚または聴覚経路によってその特定部位に活動 が生じる。この活動が, その部位の運動出力二 ューロンに伝えられると, この対象物に視線を向 けるような眼球運動の出力が生じると考兄られ る。さらに, 前頭眼野はこのような眼球運動発生 の促進機能ばかりでなく, 一旦網膜中心窩に捉兄 た視覚対象物の像を, その静止や動きに関わら
ず，中心窩に留めておく抑制機能も備兄ている。 これら促通 (facilitation) と抑制 (inhibition) の 両機能があいまって, 正常な注視行動の発現が支 えられていると考兄らる。

これらの注視機能発現に関連して幾つかの問題 がある。第一はその機能地図的な体制である。前 頭眼野及びその入出力系は, 空間の「中心一周辺」 といら原則に従って体制化して扣り, 網膜地図的 体制 (retinotopical organization) に打ける中心 窩からの方向（vector angle）についての再現は 失われている。すなわち, 中心窩からの偏心度 (vector amplitude) が同じならば, 離れた場所に 

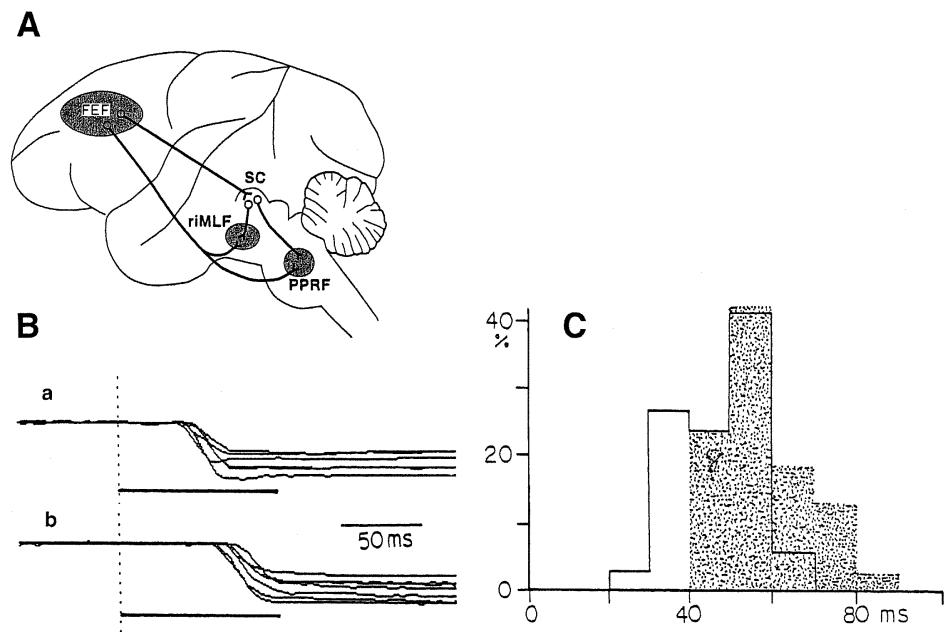

図13 A : 前頭眼野からの 2 つ眼球運動出力系。SC: 上丘, riMLF: 内側緃束吻側間質核, PPRF: 橋網様体傍 正中部。 B ：a は上丘破壊前の FEF 電気刺激誘発サッケード。bは上丘破壊後の誘発サッケード。上丘 路が無くなるとサッケード潜時が伸びる。C：上丘破壊前（実線で囲まれた部分）と破壊後（点々を打 った部分）の電気誘発サッケード潜時ヒストグラム。

現れた（vector angle が非常に異なる）刺激でも， 前頭眼野皮質の互いに近い部位のニューロン群活 動を引き起こすことになり，両刺激の相互干渉の 機会を増大させることが考劣られる。このような 点状でなく，いわば線状の再現 (linear representation) は, 視野内の複数の視覚刺激のいずれか に目を向けるかといら行動の選択に役立っている のかも知れない。また，このような体制が実験結 果を複雑にしているのかもしれない。

第二は, 前頭眼野からの運動出力はどこに行く かといら問題である。前頭前野から強力な投射が 上丘に向からことはすでに述べた。それで，上丘 を介しての脳幹の眼球運動中継核である内側縌束 吻側間質核 (riMLF) と橋網様体傍正中部 (PPRF) に達する経路がこのような機能を支えているのだ ろら。しかし, 上丘は, 前頭眼野と異なり網膜地 図的な体制を持っている。前頭眼野で一旦失われ た点状再現が，どのようにして上丘で復活する か, あるいは, 点状再現は保存されたまま, 別の 経路によって上丘に達するのであろらか。

前頭眼野からは，上丘を介さないで脳幹中継核 へ投射する経路もある (図13参照)。この機能は なんであろらか。それを調べる第一歩として，上 丘を破壊することによって上丘を介する路を遮断 したときの前頭眼野の電気刺激誘発サッケードの
変化を調べた。図13Bに示したように，上丘破 壊前の前頭眼野電気刺激誘発サッケードは, 潜時 27-66 ミリ秒（平均47 ミリ秒）で生じた。上丘破 壊すると, サッケードの誘発潜時は44-84ミリ秒 (平均 58 ミリ秒) と延びた。このことは, 前頭眼 野から上丘を介さないで脳幹の眼球運動中継核に いく経路は, 上丘を介寸る経路が働いた後に働く ことになる。あるいは，この経路は上丘を介する 経路に加えて, 眼球運動サッケードのより精緻化 に貢献しているのかもしれない。

\section{文献}

1) Akert K: Comparative anatomy of frontal cortex and thalamofrontal connection. In eds Warren JM, Akert K. The frontal granular cortex and behavior. pp 372-396, McGrawHill, New York, 1964

2) Kennard MA: Alteration in response to visual stimuli following lesions of frontal lobe in monkeys. Arch Neurol Psychiat 41: 11531165, 1939

3 ) Latto R, Cowey A: Visual field defects after frontal eye-field lesions in monkeys. Brain Res 30: 1-24, 1971

4) Latto R, Cowey A: Fixation changes after frontal eye-field lesions in monkeys. Brain 
Res 30: 25-36, 1971

5 ) Schiller PH, True SD, Conway JL: Deficits in eye movements following frontal eye-field and superior colliculus ablations. J Neurophysiol 44: 1175-1189, 1980

6 ）鈴木寿夫 : 衝動性眼球運動の高次中枢. 猪俣 孟, 玉井 信, 本田孔士編. 眼科学体系 7 . 神経眼科. 403-417頁, 中山書店, 東京, 1995

7 ) Suzuki H, Azuma M: Topographic studies on visual neurons in the dorsolateral prefrontal cortex of the monkey. Exp Brain Res 53: 47, 1983

8 ) Bruce CJ, Goldberg ME: Primate Frontal eye Field. I. Single neurons discharging before saccades. J Neurophysiol 53: 603-635, 1985

9 ) Azuma M, Suzuki H: Properties and distribution of anditory neurons in the dorsolateral prefrontal cortex of the alert monkey. Brain Res 298: 343-346, 1984

10) Suzuki H: Distribution and organization of visual and auditory neurons in the monkey prefrontal cortex. Vision Res 25: 465-469, 1985

11）鈴木寿夫, 小松英彦：前頭眼野と注視行動. 精神医学 27: 633-640, 1985

12) Bruce CJ, Goldberg ME, Bushnell MC, et al: Primate Frontal eye Field. II. Physiological and anatomical correlates electrically evoked eye movements. J Neurophysiol 54: 714-734, 1985

13) Azuma M, Nakayama H, Sasaki $Y$, et al: Relation between visual input and motor outflow for eye movements in monkey frontal eye field. Behav Brain Res 27: 93, 1988

14) Komatsu H, Suzuki H: Projections from the functional subdivisions of the frontal eye field to the superior colliculus in the monkey. Brain Res 327: 324-327, 1985

15) Stanton GB, Goldberg ME, Bruce CJ: Frontal eye field efferents in the macaque monkey: II. Topography of terminal fields in midbrain and pons. J Comp Neurol 271: 493 $-506,1988$

16) Cynader M, Berman N: Receptive-field organization of monkey superior colliculus. $\mathrm{J}$
Neurophysiol 35: 187-201, 1972

17) Guitton D, Buchtel HA, Douglas RM: Frontal lobe lesions in man cause difficulties in suppressing reflexive glances and in generating goal-directed saccades. Exp Brain Res 58: 455-472, 1985

18) Johnston JL, Sharpe JA, Marrow MJ: Spasm of fixation: a quantitative study. J Neurol Sci 107: 166-171, 1992

19) Suzuki H, Azuma M: Prefrontal neuronal activity during gazing at a light spot in the monkey. Brain Res 126: 497-508, 1977

20) Suzuki H, Azuma M, Yumiya H: Stimulus and behavioral factors contributing to the activation of monkey prefrontal neurons during gazing. Jpn J Physiol 29: 471-489, 1979

21) Azuma M, Nakayama H, Suzuki H: Suppression visually triggered saccades by electrical stimulation of the monkey frontal eye field. J Physiol Soc Jpn 48: 266, 1986

22) Burman DD, Bruce CJ: Suppression of taskrelated saccades by electrical stimulation in the Primate's frontal eye field. J Neurophysiol 77: 2252-2267, 1997

23) Lynch JC: Frontal eye field lesions in monkeys disrupt visual pursuit. Exp Brain Res 68: 437-444, 1987

24) Keating EG: Frontal eye field lesions impair predictive and visually-guided pursuit eye movements. Exp Brain Res 86: 311-323, 1991

25) Gottlieb JP, Bruce CJ, MacAvoy MG: Smooth eye movements elicited by microstimulation in the primate frontal eye field. J Neurophysiol 69: 786-799, 1993

26) Gottlieb JP, MacAvoy MG, Bruce CJ: Neural responses related to smooth-pursuit eye movements and their correspondence with electrically elicited smooth eye movements in the primate frontal eye field. J Neurophysiol 72: 1634-1653, 1994

$$
\left(\begin{array}{l}
\text { 原稿到着 : 平成 } 10 \text { 年 } 9 \text { 月 } 18 \text { 日 } \\
\text { 別刷請求先 : 鈴木寿夫 } \\
\text { † } 113-8519 \text { 東京都文京区湯島1-5-45 } \\
\text { 東京医科歯科大学医学部第一生理学教室 }
\end{array}\right)
$$

